\title{
Managing an Economy Under EMU: The Case of Ireland
}

\author{
by John Fitz Gerald, David Duffy and Diarmaid Smyth
}

ESRI Working paper No. 127

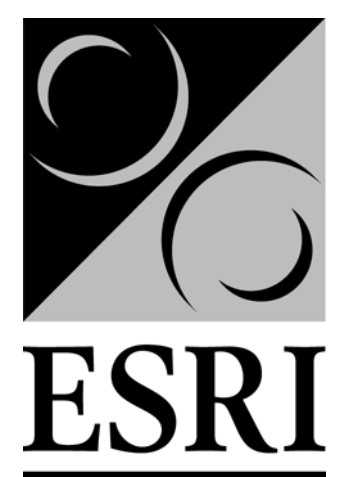

2 May 2000

THE ECONOMIC AND SOCIAL RESEARCH INSTITUTE

4 Burington RoAd, DUBLIN 4

TEL: (353-1) 6671525 FAX: (353-1) 6686231 


\section{Introduction}

Over the past 15 months the economy of the euro zone and its individual member economies have had the first experience of operating in a completely new environment. This is very much a learning process as the regime change that EMU involves renders obsolete some of the key economic relationships that would normally help Central Bankers and governments tune their instruments of economic management. It will be some time before we fully understand the factors driving the demand for money within the new Union and the process whereby the euro zone rate of inflation is determined is undergoing substantial change. All this makes it difficult for policy makers in the ECB and in individual member states to do their job.

This paper first considers the dilemma facing the ECB itself in managing the euro zone economy. It then turns to the issues facing individual governments in managing their own "regional" economies within the euro zone - in particular the issues facing the Irish government.

The reasons for small economies joining the EMU may well be different from those for larger economies. In particular the reduction in the risk premia attaching to smaller currencies, such as the Irish pound, means that such economies will experience lower interest rates in the medium term and, therefore, higher levels of investment than would be possible outside the Union. However, part of the price of this more favourable interest rate environment in the medium term is a reduction in the ability of individual member states to control their own economies in the face of a "one size fits all" monetary policy.

In considering the problems faced by governments of individual member states in the euro zone we first consider the extent to which they should be concerned about deviations in domestic inflation rates from the average euro zone rate. We identify significant benefits to EMU membership but also a cost in the reduction in the ability to control pressures on domestic property markets.

However, while the Irish government has a reduced range of economic instruments under EMU, it still has considerable scope to manage its own economy. Fiscal policy, while less effective an instrument than monetary policy for directly influencing inflationary pressures in asset markets, remains an effective instrument for moderating domestic demand pressures. It could be used both to control excess demand in the economy as a whole, and also to reduce dangerous pressures on the domestic property market. In the long run, the key elements of supply side policy, that can really make a permanent difference to growth and living standards, are unaffected by EMU. The National Development Plan will probably prove much more important to the future of the economy than will any individual budget or any decision made by the ECB.

Within EMU the parameters of domestic policy action are reduced, but not eliminated. However, this changed environment requires alterations in the way governments manage their economies, with more attention being placed on the regional impact of fiscal policy. 
Member governments have frequently stressed the need for the private sector to adjust to the regime change that EMU membership involves. There is also a need for the governments themselves to recognise this change in formulating their own policies.

Finally, this paper does not consider the problems facing regions of national economies that have very little fiscal autonomy. With the exception of the Northern Ireland Economic Council's study (Bradley, 1998), this issue has to date received little attention in the literature.

\section{Managing the Euro Today}

The US economy has experienced an exceptional period of sustained growth over the last decade. Whether or not the impact of new technology helps explain this success, what is clear is that this can not be sustained at its current rate. American households are continuing to fund the remarkable growth in consumption through ever increasing household indebtedness and the US economy as a whole is also moving ever further into debt, as reflected in the growing balance of payments deficit. The strength of the dollar means that US goods and services are now more expensive relative to European goods than they have been at any time over the last 20 years.

The momentum of growth in US consumption has exceeded the ability of the US economy to produce and, sooner or later, it must slow. Whether this slow-down occurs gradually, because more and more American households are afraid to borrow any more, or whether it occurs more rapidly as the rest of the world - the lenders - take fright, remains to be seen. Either way the overvaluation of the US dollar relative to the euro will eventually be reversed. The only question is when?

While the US is essentially a very closed economy, with import prices having a limited impact on domestic inflation, the continuing rise in the value of the dollar has exerted some downward pressure on US inflation, offsetting the effects of a tight domestic labour market. If and when the dollar reverses direction, there will be an additional external impulse to US inflation on top of domestic inflationary pressures. This could prove unfortunate, necessitating a further rise in interest rates at a time when the economy was already slowing.

The moral of the story is that US monetary policy has been too lax for some time possibly for political reasons in the run up to the US presidential election. Demand in the US has grown more rapidly than supply and the resulting overvaluation of the dollar (and of the US stockmarket) holds the seeds of a possible sudden and destabilising reversal of fortunes.

The uncertainty about the future of the US economy poses a problem, not just for the governor of the Fed, Mr. Greenspan, but also for the ECB and Mr. Duisenberg. The EU economy is at last beginning to pick itself up off the floor with relatively rapid growth in both the German and the French economies last year and this year. Relaxed monetary policy has helped promote such a recovery. However, with the weakness of the euro there has been some increase in inflationary pressures within the euro zone, driven by rising 
input costs. Goods priced in dollars inevitably cost more and the dollar price of oil, in particular, has risen.

To keep EU inflation this year below 2 per cent interest rates should probably be higher than they are now. However, the dilemma for Mr. Duisenberg and the ECB is that they know that at some stage in the next few years the positions of the euro and the dollar will be reversed, with the dollar falling significantly in value vis à vis the euro. If that were to happen within the next two years, the EU economy would find itself facing a much less competitive environment and one with much reduced inflationary pressure.

If the ECB were to substantially tighten monetary policy at this point it could well induce such a reversal in the relative value of the dollar and the euro, slowing the nascent euro zone recovery. This in turn would render the stance of EU monetary policy too tight.

The underlying problem facing central banks on either side of the Atlantic is the likelihood that, when the time comes for economic fundamentals to reassert their influence on exchange rates, the resulting change in exchange rates will not be smooth. Very rapid changes can occur over a short period of time. This was the experience in the 1980s when the DM fell against the dollar by 40 per cent between mid 1980 and mid 1981 and, when the time came to reverse the process in 1985, the dollar in turn fell by nearly 30 per cent against the DM over the course of the following year. This demonstrates that a monetary policy stance that is appropriate to the short-term needs of an economy before such a change, will almost inevitably be seen to be inappropriate immediately after the change.

This is why the objective of controlling inflation in the EU has to be set in a mediumterm context - and temporary deviations in the rate of inflation from its long-term trend may have to be accepted. Under these circumstances it is appropriate for the ECB to follow the current approach of tightening monetary policy gradually, focusing on the future when the value of the euro will move back into line with the value that economic fundamentals would dictate. To focus on short term currency gyrations, induced by the lemming-like behaviour of the financial markets, could destabilise the real economy of the euro zone, and ultimately be very counterproductive.

In so far as mistakes are currently being made in monetary policy, they are occurring on the other side of the Atlantic. Once the US elections are over it will then be more than time for the Fed to begin the process of winding the US economy down from its current frenzied state. However, it will be a dangerous process for the US economy and, because of its significance for the world as a whole, and for Ireland in particular, the rest of us could find the ride uncomfortable.

\section{The Benefits and Cost of Membership - Risk Premia}

Membership of the Economic and Monetary Union since its inception in January last year has undoubtedly led to some restriction on the scope for independent policy action in Ireland. This loss of an important policy instrument must be considered in the light of the potential benefits that are expected to arise from membership. Much of the discussion in 
Ireland and elsewhere of the costs and benefits of EMU membership has focused on essentially short-term gains or losses. However, the decision on membership involved a permanent commitment to a new policy regime and it was only appropriate that the benefits and costs be assessed on a long-term basis - what would be the effects on the economy over at least a ten or fifteen year time horizon.

One of the key long-term reasons why membership of EMU was considered desirable for Ireland was the expected long-term impact on interest rates and the cost of capital. When the decision on membership was made there was extensive evidence from 15 years of monetary independence that that independence was bought at the cost of much higher interest rates (Honohan, 1993). Figure 1 shows the cumulative "excess returns" from lending in Irish pounds compared to DMs over the period 1979-99. As shown in Figure 1, the relative cost of borrowing in Irish pounds compared to borrowing in DMs carried a substantial excess over the full 20 year period of monetary independence. Even allowing for exchange rate changes, the higher Irish pound interest rates over the 20 years would have resulted in a cumulative 50 per cent higher return on Irish pound lending than DM lending. This amounts to an excess return of 2 percentage points a year.

Figure 1: Cumulative Excess Returns

$$
\text { Relative to the DM }
$$

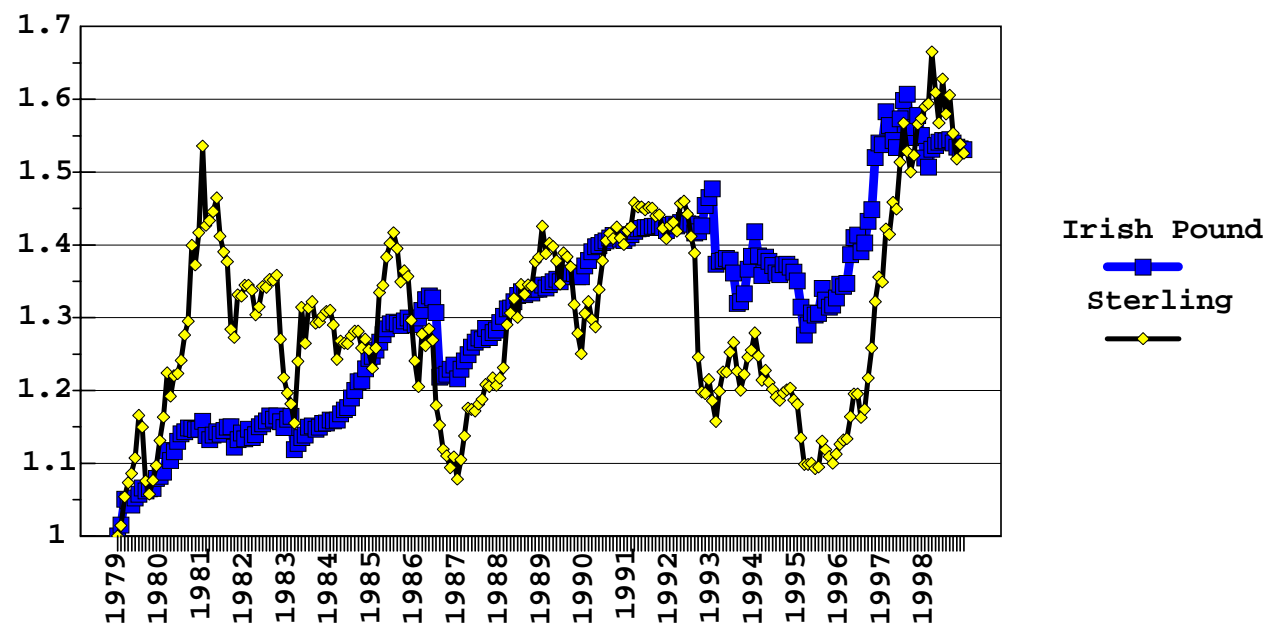

The fact that the cost of capital was so much higher in Ireland than in Germany over all of that period had a serious negative effect on the level of investment and, as a result, on the potential growth rate of the economy. Investment by the private sector across a wide range of assets was substantially reduced and, especially in the 1980s when the public finances were in disarray, the higher interest rates led to underinvestment in public infrastructure.

In the light of the crisis in the public finances in the 1980s and the poor performance of the economy generally it was not surprising that the financial markets exacted a substantial price for lending in Irish pounds. The cumulative excess returns between 1979 and 1988 were 34 per cent or just under 3 percentage points a year. However, over the 
course of the 1990s the Irish economy performed much better and the public finances strengthened continually over the period, yet the cumulative excess returns between the beginning of 1989 and the end of 1998 were 14 per cent, and the average annual excess return was 1.4 percentage points.

How can this excess be explained? In the 1980s the explanation seems obvious - a significant risk premium attached to the Irish economy because of poor domestic management, a crisis in the public finances, and the potential for a serious collapse due to the ballooning national debt. However, none of these arguments applied to the 1990s when the economy was well managed and the debt has fallen dramatically.

It would seem that there are other factors at work. It is instructive that under EMU, where no exchange risk applies, the margin attaching to Irish government borrowing (and that of some other smaller economies) compared to German borrowing is around 0.25 percentage points. ${ }^{1}$ It may well be the case that, for a small currency, the price of information to the financial markets is quite high. In the past, if a financial institution wished to invest in Irish pound assets they would have to study the prospects for the Irish pound as well as the prospects for the Irish public finances. In the 1990s, with many other similar government bond offerings from larger economies, the cost of studying the Irish economy may not have been warranted.

In the light of this evidence, the 1996 study of the prospects for Ireland in EMU (Baker et al., 1996) took the view that the excess returns in the long run would fall to one percentage point if Ireland were to remain outside EMU. The cost of such a permanent wedge in the cost of capital was considered to be quite high. It would have resulted in the economy underperfoming on a long-term basis as investment was kept below its potential.

It is interesting to examine the situation elsewhere in this regard. The Swedish government report (Calmfors, 1997) on EMU entry, that paralleled the Irish one, also considered this issue. They too found that in the past there had been a significant risk premium attaching to Swedish kroner assets. However, in their case they felt that, with rational markets, the premium would eventually disappear.

Finally, it is interesting to consider the position of the UK, a large economy with a currency that is studied by all major financial institutions. Figure 1 also shows the excess returns on sterling assets compared to DM assets over the same 20 year period as for the Irish data. While the pattern is much more bumpy compared to the steady rise in the Irish series, by the end of 1998 the excess returns on sterling assets were almost identical to those on Irish pound assets. Over the period 1979 to 1998 the excess returns on sterling assets was also 2.1 percentage points a year.

Whether or not this had a significant impact on the UK economy's performance over the past 20 years depends on how sensitive it was to changes in the cost of capital. Certainly

\footnotetext{
${ }^{1}$ This margin probably reflects differences in the liquidity of the different instruments.
} 
the much lower level of public debt than in the case of Ireland would suggest a lower sensitivity. Also the excess returns were highest in the 1980s, falling to just under one per cent a year between 1989 and 1998.

Looking to the future, one would expect that the cost of information about the UK economy would be lower than for smaller economies. As a result, the future premium that the financial markets will require to lend in sterling will probably be lower than for smaller, less well-known economies, such as Sweden or Denmark. However, on the basis of the evidence of the 1990s, it would seem that some risk premium will continue to be charged in the future on sterling assets. This will represent part of the cost to the UK of remaining out of EMU, a cost that must be offset against the other benefits that enhanced policy independence is likely to confer.

The major potential cost for the Irish economy from EMU membership arises from the increased policy inflexibility, due to the loss of an important instrument - monetary policy. In the 1996 report, a number of scenarios were considered to see how the economy would react to shocks both in and out of EMU. Among the shocks considered were a sudden loss of competitiveness against sterling as well as a major rise in the value of sterling.

What these simulations showed was that there were likely to be significant costs arising from the loss of flexibility consequent on EMU membership. In particular, in 1996 a sudden major loss of competitiveness against sterling would have imposed substantial temporary costs on the economy.

The approach adopted in Baker et al., 1996, involved firstly deriving an estimate of the potential cost of shocks. This was done by simulating the external effects of the shock using the National Institute for Economic and Social Research's NiGEM model and the domestic effects were then examined using the ESRI's HERMES model. This analysis used the example of a sterling shock to estimate the cost of shocks under varying exchange rate regimes - Ireland in and out of EMU.

Table 1: Medium-Term Effects of Irish Membership of EMU Average change in level compared to benchmark

\begin{tabular}{lcc}
\hline \hline & $U K$ Out & UK In \\
\hline Effects of: & \multicolumn{3}{c}{ Change in GNP, \% } \\
\hline Transactions costs & 0.1 & 0.1 \\
Interest Rates & 1.7 & 1.7 \\
Competitiveness - steady state & -0.4 & 0.0 \\
\hline Cumulative Effect - Tranquil Scenario & 1.4 & 1.8 \\
Risk of Shocks - Competitiveness etc. & -1.0 & -0.4 \\
\hline Net Effect & 0.4 & 1.4 \\
\hline & Change in Employment, (000) \\
\hline Net Effect & 10,000 & 20,000 \\
\hline \hline
\end{tabular}

Having arrived at an estimate of the cost of shocks the second task was to derive a weight to attach to the calculated cost. This weight should reflect the expected frequency and intensity of future shocks. The past experience of the sterling - DM exchange rate was used as an indicator of the frequency and intensity of future shocks. If either changes in 
UK policy or the creation of the EMU itself were to reduce the volatility of the future euro-sterling rate this could reduce the cost of shocks below what was estimated. Finally, account was taken of the fact that a reasonable exchange rate policy outside EMU would not eliminate all of the shocks. (Indeed, the exchange rate policy assumed in the simulations would have eliminated less than a half of the effects of these shocks.)

Using this information in an appropriate model, the report arrived at an overall assessment of the allowance which should be made for the possible cost of future shocks under different exchange rate regimes. It can be seen as the insurance premium which it would be worth paying to buy protection against future shocks.

The result of applying this methodology suggested that the allowance for the avoidable cost of shocks need be no higher than the annual equivalent of 1 per cent of GNP. This is insufficient to offset the estimated steady gains of around 1.4 per cent of GNP, largely arising from the lower risk premium on interest rates in the long run(Table 1). Having made provision for the cost of possible shocks, the net benefit of EMU membership in terms of employment was estimated to be of the order of 10,000 .

These quantified macroeconomic benefits of lower interest rates and risks of adverse currency movements were both rather smaller than might have been expected.

The report also identified a number of other potential but unquantifiable effects of joining EMU, some of which could be substantial. They include the impact of commitment to Europe and increased currency stability on business confidence and investment plans among Irish and overseas investors. They also include wider political factors which are inherently unquantifiable. These unquantified effects seem likely to enhance the probability that EMU membership will prove beneficial.

On balance, for Ireland, the quantified effects in the 1996 report indicated that EMU membership is likely to provide a modest benefit in terms of output, employment, and trade. When the unquantified effects are included the benefits from membership are likely to prove more significant. If the UK were to join the EMU then the gain from membership for Ireland would be further enhanced. However, even then, the probable net benefits would still be on a smaller scale than the net gains from the completion of the Single European Market (SEM) in 1992 or from the inflow of European Structural Funds over the past decade.

\section{Regime Change Affects Members and Non-Members}

It was clear at the outset that EMU would affect the behaviour of the economies of all the members in a wide range of different ways. However, what was possibly less obvious, was that even for non-members within the EU, EMU would also represent a regime shift. For the Irish economy it is of particular interest how the UK reacts to the changed environment.

The Irish retail sector is dominated by UK firms and quite a high proportion of goods sold in Irish shops are sourced in the UK. Studies of the Irish rate of inflation in the past 
have indicated that inflation was driven by changes in consumer prices in the UK and changes in the bilateral exchange rate (Fitz Gerald and Shortall, 1998). Generally, changes in the exchange rate take some time to feed through to Irish prices. In addition, if sterling moved unilaterally against all other currencies the rate of pass-through would be greatly attentuated.

Figure 2 considers the forecasting power of such a model using data available up to early 1998 (Fitz Gerald and Shortall, 1998). It contrasts the forecasts produced by the model from 1998Q1 to 1999Q4 with those produced by a simple PPP model between Ireland and Britain which takes no account of the position of the UK price level relative to its equilibrium level. $^{2}$

As one would expect, the significant appreciation in sterling in 1997-98 fed through fully into the simple PPP model, an inflation rate of almost 8 per cent being predicted by the end of 1998. The adjusted PPP model, which allows for the fact that the UK exchange rate in 1998 was not expected to persist, produced forecasts which were much lower. It took account of the UK's position compared to its equilibrium price level.

Figure 2: Forecasts of Irish Constant Tax Price Inflation

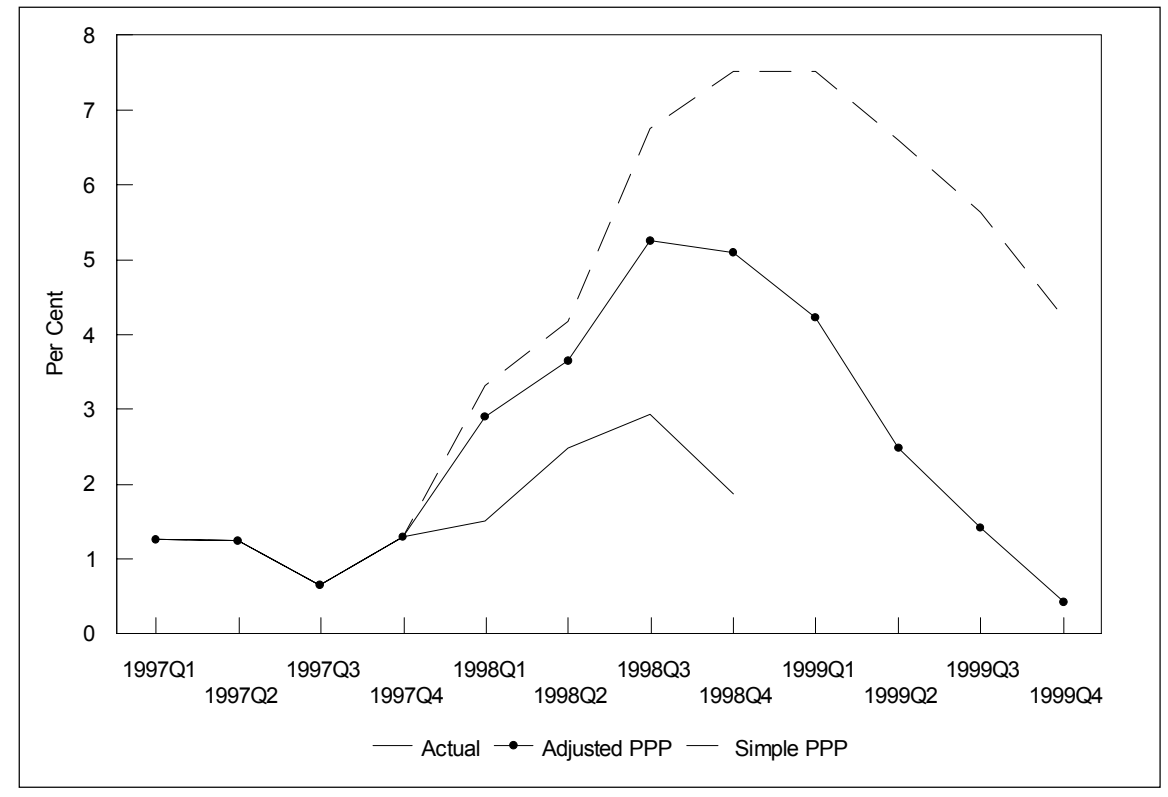

Both, however, gave significantly higher predictions for 1998 than was actually the case. The Irish pound fell against both sterling and the Deutschmark during this period, so much of the change in the exchange rate wasn't counteracted by an increased deviation of UK prices from trend, resulting in a prediction of accelerating inflation. This overprediction provides early evidence that a regime change is under way as more and more British firms begin to price in euros. McArdle, 2000, provides additional supporting

\footnotetext{
${ }^{2}$ It took forecasts for the UK from the National Institute of Economic and Social Research's NiGEM model (NIESR, 1997).
} 
evidence, indicating that UK firms are increasingly pricing in euros rather than in sterling so that they carry the cost of unexpected exchange rate changes.

What appears to have happened is that UK firms, fearing increased competition on the broader euro-zone market, including Ireland, moved to setting prices in euros. As a result, they tended to hold their prices relatively unchanged in Irish pound terms, fearing a loss of market share if they did not. Effectively the UK suppliers on the Irish market are behaving as price takers. The UK manufacturer or supplier, therefore, largely carries the cost of this failure to adjust prices in the form of reduced profit margins. Hall, Walsh and Yates, 1997, using data from a Bank of England survey carried out in 1995, found that market levels are of primary importance in price determination for UK companies. Furthermore, the survey found that companies typically reviewed prices at regular time intervals, rather than responding to particular events.

The inflation outturn in Ireland in 1998 and 1999 was different from what would have been suggested by models of inflation based on past behaviour. Under the previous model of inflation, while the pass through of an appreciation of sterling would have been slow, some of the appreciation would eventually have shown through in Irish prices. This certainly had not happened up to mid-1999. The evidence from the last two years would, thus, suggest a change in behaviour by UK firms moving them, if not the UK economy as a whole, into the euro-zone.

An example, of this strategic behaviour by firms in the face of exchange rate uncertainty was the response by an Irish firm, the Irish Distillers Group in 1987, faced with rapidly changing exchange rates. They responded to a query from the Restrictive Practices Commission explaining differences in the net of tax prices for their product North and South of the border:

“The company's N.I. price list was fixed in 1986 on a projected value of the Irish pound to sterling of $85 \mathrm{p}$ and this value should be used to give a true indication of the difference." 3

The fact that their expectations about the exchange rate were not realised immediately did not cause them to change their prices. Their forecast for the exchange rate, while wrong for the period in question, proved reasonably accurate for 1988 and 1989. What this shows is that exchange rate expectations are at least as important in determining economic behaviour as is the actual current exchange rate.

For Irish exporters on the UK market there is some evidence that they have seen an improvement in profit margin as they failed to fully cut the sterling price of their goods as sterling strengthened. However, the evidence from the wholesale price index and the deflator for exports in 1998 and 1999 suggests that the extent of profit-taking has been

\footnotetext{
${ }^{3}$ Restrictive Practices Commission, 1987
} 
relatively low. ${ }^{4}$ The latest data for end 1999 does suggest a pick up in such prices, but much of this may be accounted for by other factors, such as the rise in oil prices.

\section{Ireland's Exposure to Sterling}

We consider here a range of indicators of how the structure of the Irish economy has changed in recent years. The general import of these indicators is that the economy has become steadily less dependent on the UK, with the pace of change, if anything, increasing in recent years.

Figure 3: Share of Irish Trade with the UK, 1960-1998

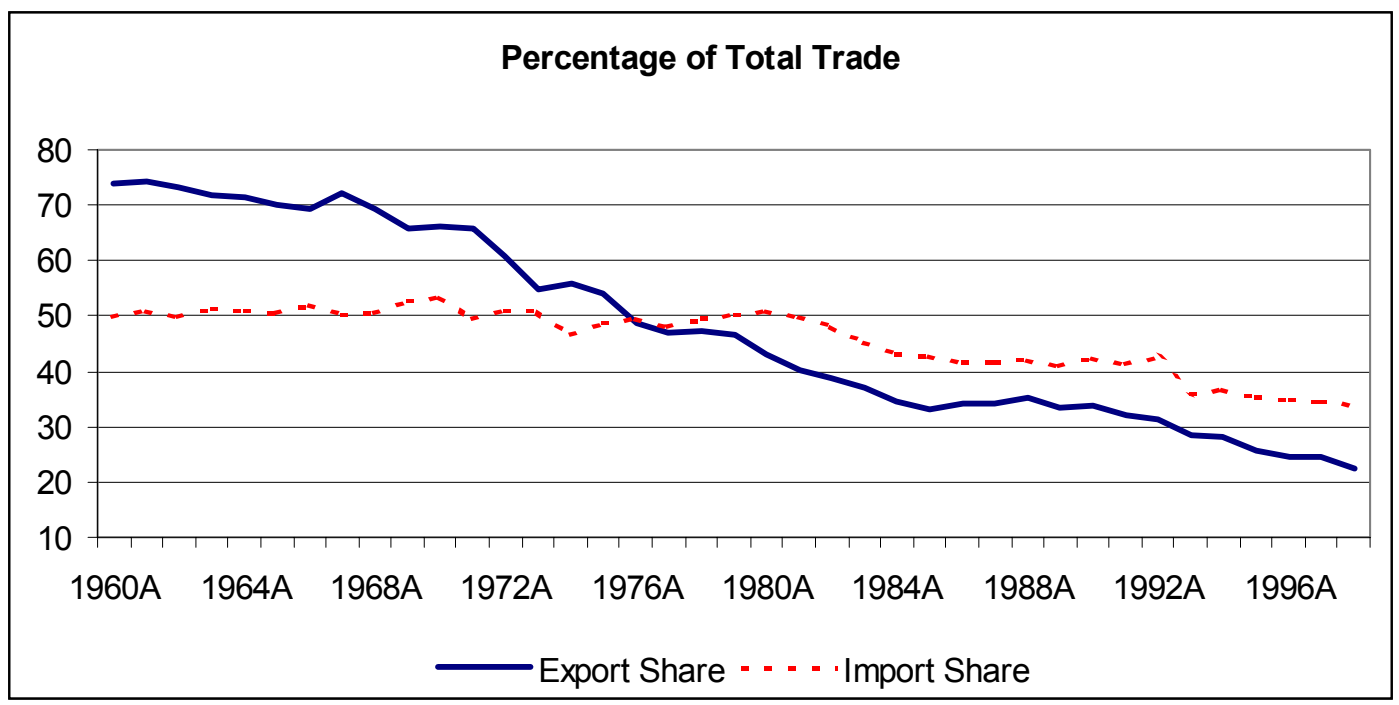

Figure 4: Share of Irish Trade with the EU excluding the UK, 1972-1998

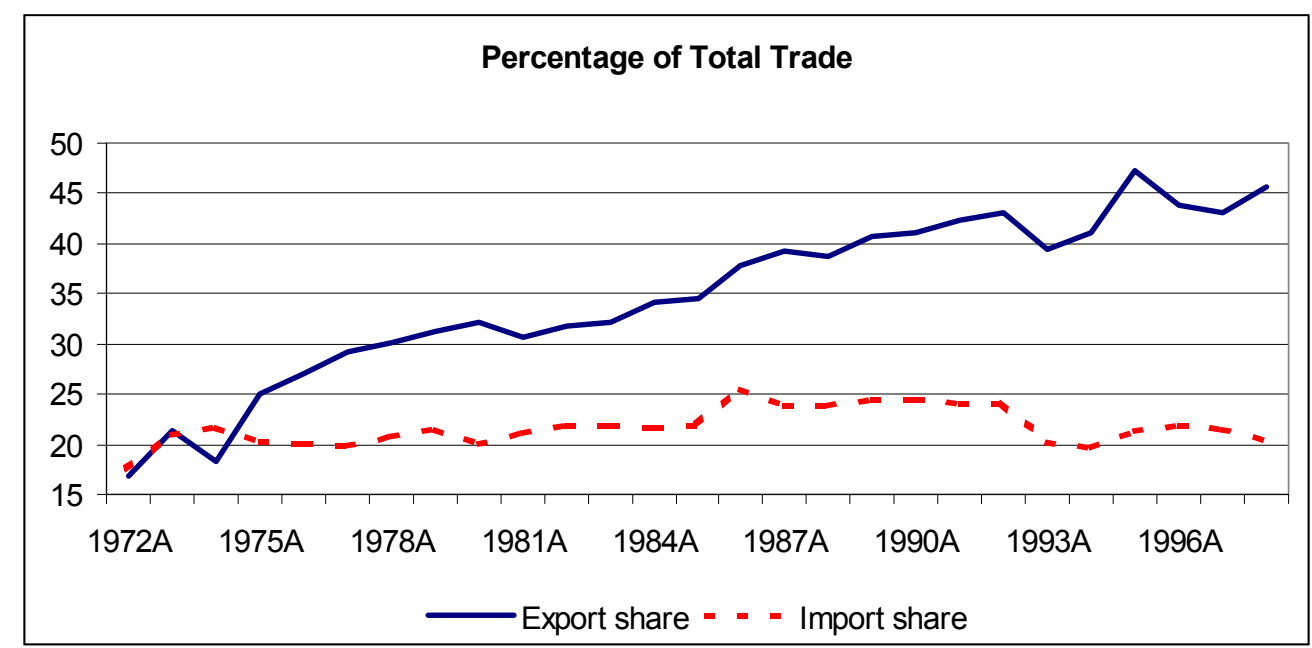

\footnotetext{
${ }^{4}$ In addition, for some of the high-tech. manufacturing firms both their inputs and their outputs are effectively priced in dollars. In this case it is the strength of the dollar rather than the strength of sterling that is important.
} 
Exposure to a sterling shock depends on the structure of the Irish economy and the behaviour of the economic agents that operate within the economy. Historically the UK has been a very important economic neighbour in terms of trade and, indeed, in terms of the labour market. Figure 3 shows that the UK's share of Irish imports and exports has declined steadily since 1960. Having averaged 71 per cent between 1960 and 1969, export dependency had fallen to 22.6 per cent by 1998 . The decline in import dependency is less dramatic. From an annual average of 51 per cent during the 1960s, import dependency had fallen to 34 per cent by 1998.

Declining dependency on the UK means increasing dependency on other economies as a market for exports and a source of imports. Figures 4 and 5 show the share of Irish trade with the EU (excluding the UK) and the share with the US and Canada. For the EU (excluding the UK) there has been a marked difference in the performance of exports and imports. The EU market has become increasingly important as a destination for Irish exports. Having accounted for 21.3 per cent of exports in 1973, it accounted for 45.7 per cent of Irish exports in 1998. In contrast, continental Europe has remained broadly static as a source of Irish imports.

Figure 5: Share of Irish Trade with US and Canada, 1975-1998

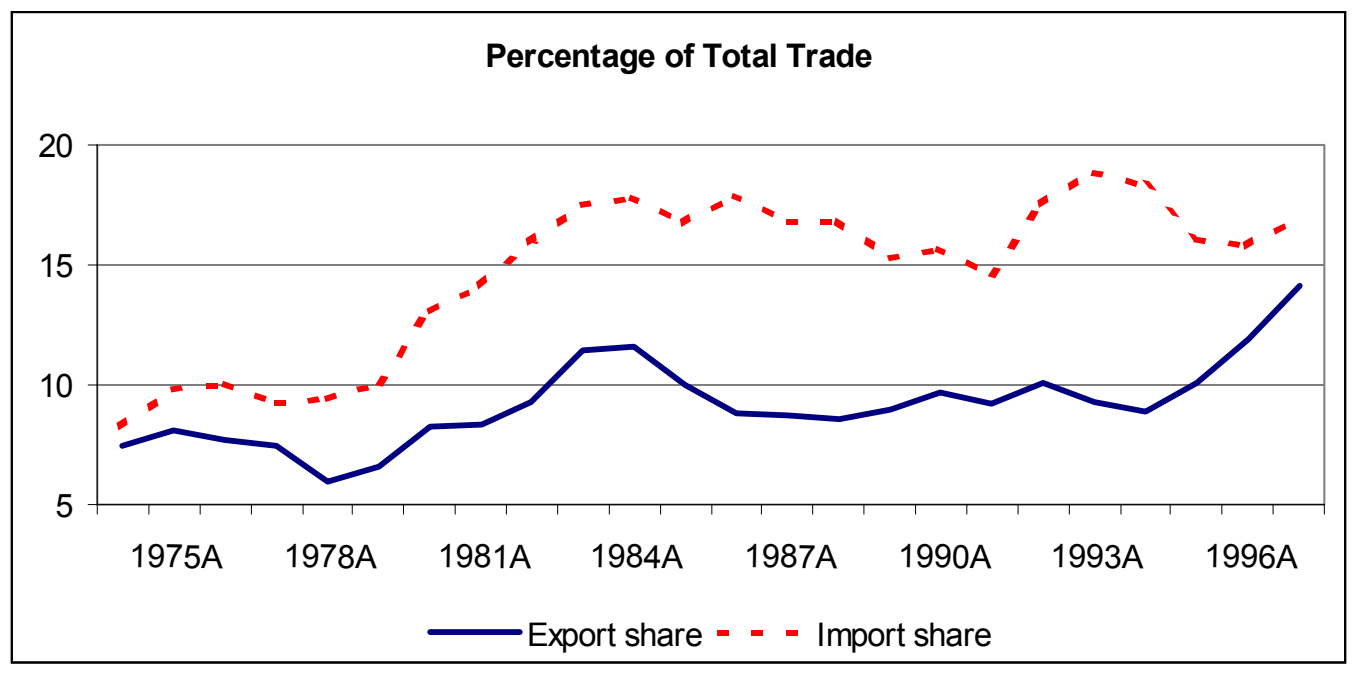

Analysis of the share of Irish trade with the US and Canada since 1975 (Figure 5) points to an increasing export and import dependence. Exports and imports with this region were low in 1975 at 7.4 per cent and 8.2 per cent respectively. In both cases the increase in share has been substantial. In the case of export this increased to 14.1 per cent by 1998 , while the import share increased to 17 per cent over the same time period.

The report on the Economic Implications for Ireland of EMU (Baker et al., 1996) examined the exposure of manufacturing to a sterling shock. The study considered both the currency exposure of individual sectors and their sensitivity to sudden interest rate changes. Based on data to 1993, this analysis found that the sectors which were most exposed to a potential currency risk were those with a considerable proportion of their output sold in the UK market and with a domestic market which was subject to extensive 
UK competition. The fast-growing export-oriented sectors appeared to be relatively insensitive to the level of Irish interest rates and little affected by sterling exposure. Of the 40 industrial sectors considered, one sector, clothing, was highly exposed to variations in the sterling exchange rate and another three (two processed food sectors and textiles) were fairly highly exposed. A further 11 industrial sectors were assessed as moderately exposed to sterling fluctuations. The remaining 25 sectors appear to have had a sterling exposure ranging from fairly low to low, because they either served mainly non-UK export markets, or had a large and reasonably protected domestic market.

Figure 6: Currency exposure

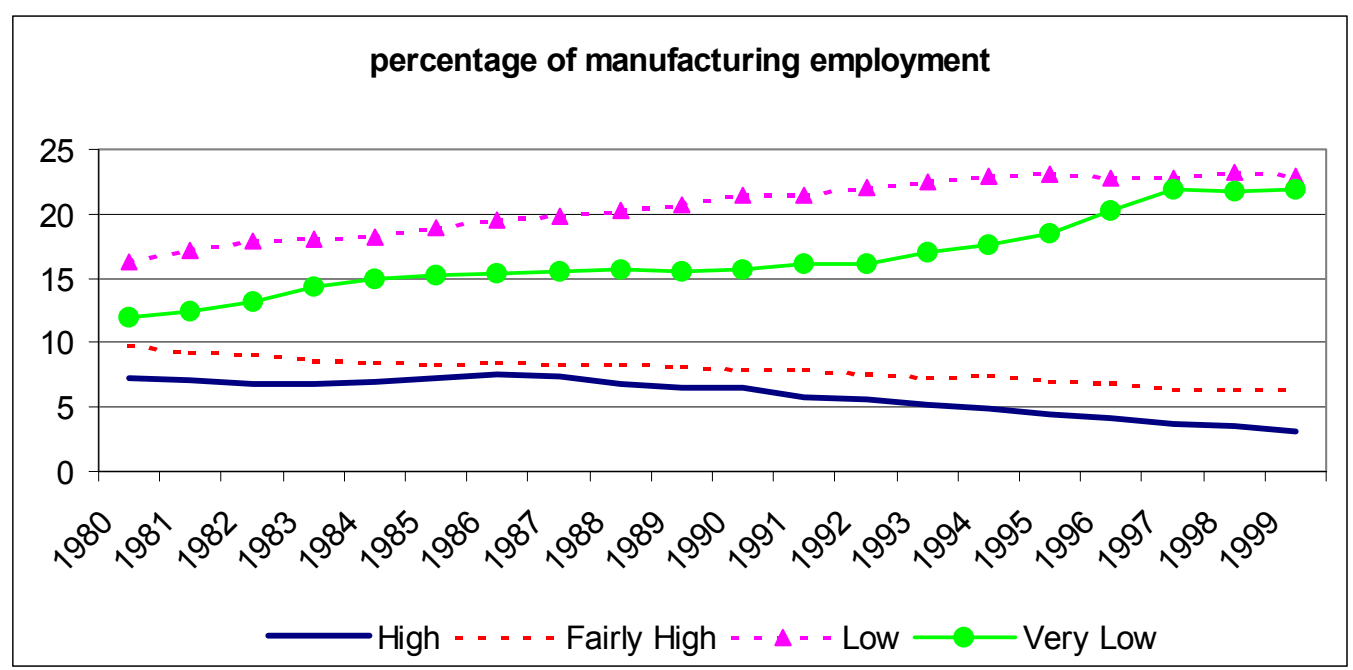

Employment figures for the different sectors identified in the EMU study have been calculated for the period 1980 to 1999 to determine the exposure of the manufacturing sector has changed. ${ }^{5}$ In terms of currency exposure there has been a decline in employment in sectors that were assessed as having a high or fairly high currency risk. In 1992 these sectors, clothing, meats, sugar and cocoa confectionery and other textiles, accounted for around 25,500 jobs, or 13.3 per cent of total manufacturing employment. By 1999 this had declined to just over 22,000, or 9.5 per cent of employment in manufacturing. This suggests that, while overall employment levels within these sectors have not declined markedly, growth in manufacturing employment has reduced the importance of these sectors, as shown in Figure 6. It is also worth noting that the sectors that had a low or very low currency exposure have increased in importance with numbers employed increasing from 73,450 in 1992 (38.2 per cent of manufacturing employment) to 105,050 in 1999 (45.1 per cent of those employed in manufacturing).

Similar analysis in the EMU report of the sensitivity to changes in Irish interest rates suggested that 8 industrial sectors had high or fairly high sensitivity to interest rates changes. These sectors included clothing and various other industries dependent on the

\footnotetext{
${ }^{5}$ To ensure that the data are as up to date as possible we have used the Quarterly Industrial Inquiry rather than the Census of Industrial Production, which provides greater detail.
} 
domestic market. A large group of 16 industrial sectors were assessed as moderately sensitive to interest rates. The remaining sectors appear to have had relatively low interest rate sensitivity. As is shown in Figure 7 there has been a marginal decline in the sectors having high interest rate sensitivity, namely minerals, and building materials. In 1992 these sectors accounted for 5.4 per cent of manufacturing employment, or 10,650. By 1999 employment in the sector had risen to 11,250. However, growth in total employment has resulted in the sector accounting for 4.7 per cent of manufacturing employment. For the sectors considered with a "fairly high" interest rate exposure, employment in absolute levels increased slightly from 36,725 in 1992 to 37,200 in 1999. However, the proportion of total employment in these sectors also fell from 18.6 per cent to 15.5 per cent. As is evident from the Figure, since 1992 there has been a sharp increase in the proportion of employment with a "very low" interest rate exposure. These sectors are for the most part the high-technology firms and include recorded media, high-margin chemicals, office machinery and computers, and high-margin food. Employment in these sectors increased from 22,425 in 1992 , or 11.4 per cent, to 36,650 or 15.2 per cent of employment in 1999.

\section{Figure 7: Interest Rate Sensitivity}

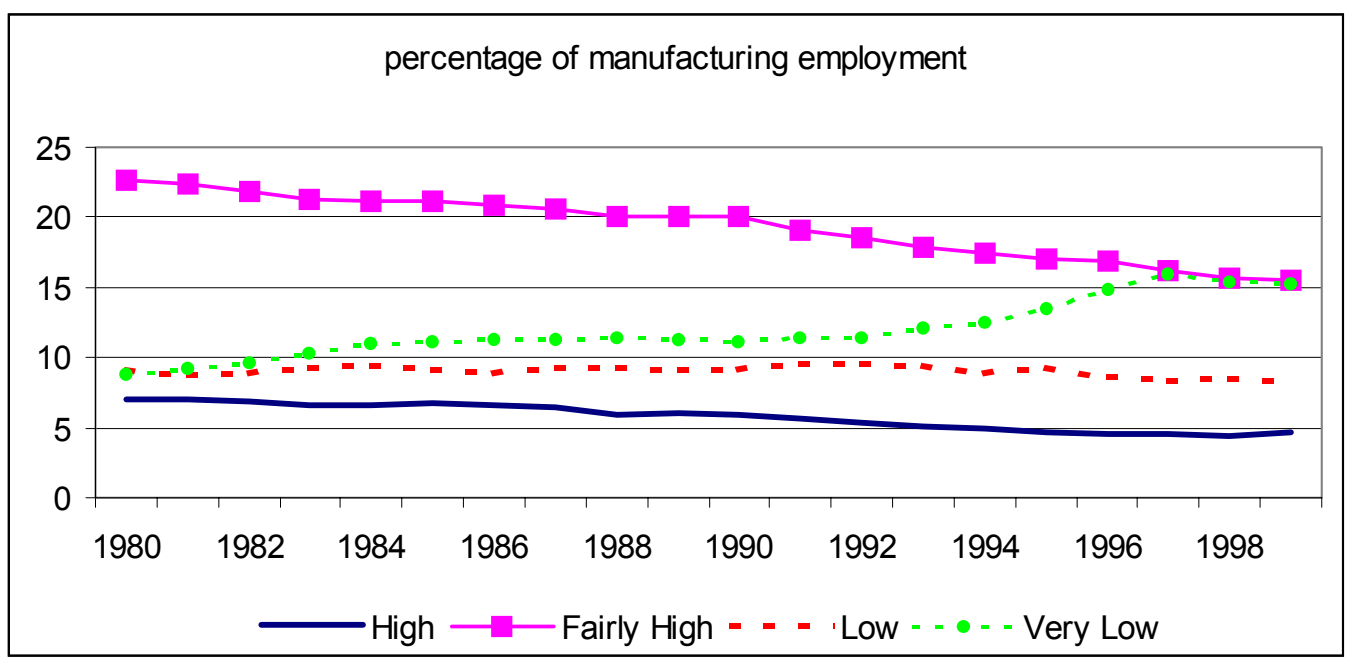

This analysis of employment trends since the 1996 report was published, suggests that the proportion of manufacturing employment in sectors particularly exposed to sterling fluctuations (or relatively sensitive to Irish interest rate movements) has declined substantially.

Over the last ten years the ESRI HERMES model of the Irish economy has been used extensively for policy simulation and forecasting. Since it was first estimated, with data for the period 1974 to 1987, it has been re-estimated every two or three years. Each time more recent data have been included, the sensitivity of the manufacturing sector to changes in labour cost competitiveness is seen to have fallen. On the other hand, the sensitivity to interest rates has risen over time. Given the decline in the proportion of employment in manufacturing in sectors particularly exposed to interest rate fluctuations, this change in the model implies some more generalised increased interest rate 
sensitivity, both in manufacturing sectors not previously considered very exposed, and also elsewhere in the economy. With the big increase in the share of resources now devoted to investment, especially in housing, this change in exposure demonstrated in the model is not very surprising.

This change in model behaviour reflects the changing structure of the economy as many firms in the tradable sector that were vulnerable to competition from low cost countries have gone under, and been replaced by new high technology firms. As identified above, this is reflected in the decline in the number of manufacturing firms vulnerable on labour cost grounds to a sterling shock. It also underlies the changing structure of Irish trade.

\section{Potential Effects of Shocks}

The potential impact of a major change in the bilateral sterling-euro (Irish pound) rate depends to a major extent on where the two economies are beginning from - is sterling overvalued or undervalued. It also depends on whether the change in the exchange rate is perceived to be permanent or temporary.

For example, if sterling and the Irish pound were initially at levels that were consistent with the underlying economic structures of the two economies, and if, as a result, prices and wages had also fully adjusted to that rate, then any new change in the rate that was perceived to be permanent would have an economic effect. It would result in a change in prices and wages in the two economies and it would also affect the long-term relative competitiveness of the two economies. In turn, the perceived change in profitability could affect investment flows.

However, if sterling was beginning from a position where it was considered very "overvalued" in terms of the euro, and if everyone had assumed that this overvaluation was temporary, then prices and wages might not have adjusted to this "temporary" overvalued exchange rate. Firms would continue to supply each other's markets anticipating that future exchange rate changes would restore the profitability of such sales to a "normal" level. In this latter case, a reversion of sterling towards what might be considered its "equilibrium" rate might have little effect. Prices, not having changed in response to the overvaluation, would not change in the face of a depreciation. Firms would also not change their output and sales as there was no change in their expected long-term profitability.

The evidence suggests that today sterling is grossly overvalued from the point of view of economic fundamentals - estimates range from 15 per cent to 25 per cent. Prices within the UK, expressed in a common currency, are out of line with those in Ireland or elsewhere in the euro zone. Instead of the UK price level falling to bring UK prices (and wages) back into line with their normal relationship vis a vis competitor countries, firms are waiting for the exchange rate itself to undertake the adjustment. However, as discussed earlier, in their trade with the outside world there are signs that UK manufacturers are behaving differently from the past. 
The effect of the high valuation of sterling over the last two years has been to squeeze profitability of UK firms and, to some extent, to enhance the profitability of Irish firms exporting to the UK over the period. What is difficult to assess is the extent to which this change in profitability, that firms themselves may regard as temporary, has affected investment. If the high valuation of sterling had been regarded as permanent then one would have expected to see a shift in investment, with firms closing in the UK and firms opening in Ireland just because of the exchange rate change. However, while the economy in Ireland has been very successful over the period, it seems unlikely that much of the investment in the business sector has been driven by the current sterling value. The cost of making an investment, and the time-lags inherent in any major investment decision, means that it must be a "forward looking" choice by firms. It is their expectations about future profitability a number of years ahead that determines the choices made by firms. It is only where firms have spare capacity North and South of the border, as in the case of some food processing plants, that output can rapidly be shifted to take advantage of temporary changes in exchange rates. However, this must be seen as the exception rather than the rule.

On the basis of the above analysis, the effects of a sudden large depreciation in sterling can be classified into three different scenarios. The likely impacts of these different scenarios were examined using the NiGEM world model and the HERMES model of the Irish economy.

1. In the first case it is assumed that firms have not adjusted their prices to sterling's high value so that an unwinding of the current position would have no direct effects on the rate of inflation in Ireland or the UK. We then consider how the loss of competitiveness faced by Irish firms impacts on the economy. Because there is no chance under this scenario of Irish firms' costs adjusting downwards or of UK firms' costs adjusting upwards, this produces the most adverse long-term impact on competitiveness.

2. The second scenario we consider is where UK and Irish prices are assumed to have adjusted to the high value of sterling. In this case, because prices and wages can adjust in the long run, the long-term loss of competitiveness is small, though the short-term loss is similar to that in the first scenario.

3. The final "extreme" assumption is that firms in the UK and Ireland have continued to make key decisions based on their expectations concerning the long-term bilateral exchange rate, which is very different from the current rate. As a result, under this scenario, a movement of sterling that validates these expectations could be expected to have little or no economic effect.

The research evidence discussed above is not sufficiently conclusive to allow us to say exactly where the Irish and UK economies lie within the boundaries delineated by these three Scenarios. What does seem clear is that sterling is overvalued (or the euro undervalued). Price and wage levels in Ireland and the UK have not fully adjusted to the current situation. However, firms, while generally discounting the current strength of sterling, have probably built its strength into some decisions on output (e.g. vulnerable 
firms staying in business) or investment. Scenario 2, where prices and wages are assumed to have fully adjusted in both Ireland and the UK to the current exchange rate, is not consistent with the evidence on price levels. As a result, the most probable outcome lies somewhere between scenarios 1 and 3 .

Table 2: Effects of Different Shocks on the Exchequer

\begin{tabular}{lcccccccc}
\hline & \multicolumn{4}{c}{ GNP } & \multicolumn{3}{c}{ Debt/GNP Ratio as percentage of GNP } \\
\hline & Scenario 1 & Scenario 2 & Scenario 3 & US Equity & Scenario 1 & Scenario 2 & Scenario 3 & US Equity \\
Shock & & & & Shock & & & & 0.6 \\
Year 1 & -1.2 & -2.5 & 0 & -3.0 & 0.3 & 0.6 & 0.4 \\
Year 2 & -1.9 & -1.8 & 0 & -3.5 & 1.2 & 0.7 & 0 & 5.3 \\
Year 5 & -2.0 & +1.4 & 0 & 0.6 & 3.2 & -2.3 & 0 & 3.8 \\
\hline
\end{tabular}

Table 2 shows the cumulative impact of a series of shocks on the level of GNP and on the debt/GNP ratio after one, two and five years respectively. For comparative purposes we have also included the possible impact of a US equity price shock, a scenario that is described in detail in the Medium-Term Review: 1999-2005. The shock involving US equity prices falling by 25 per cent was assumed to have a serious impact on foreign direct investment into Ireland, triggering a collapse in Irish house prices. Such a shock would have a much greater impact on the Irish economy than would any of the sterling shock scenarios considered here.

From the point of view of the public finances the worst case scenario for a sterling fall of 25 per cent is scenario 1 . However, even with such a shock the likely maximum impact on exchequer savings would be under one percentage point of GNP and the cumulative increase in the debt / GNP ratio after five years would be 3.2 percentage points. As discussed above, because the most probable outturn from a sudden sterling depreciation would lie between Scenarios 1 and 3, this would suggest that the economy generally, and the public finances in particular, are not very exposed to sterling shocks. However, if the shock were sufficiently great to trigger a collapse in Irish house prices then these results would be significantly magnified.

When the results of a sterling shock under different scenarios are compared with the results from a shock to the US economy the latter would appear to be much more serious from the point of view of the economy as a whole, and the exchequer in particular. This suggests that the Irish economy is now more exposed to the US economy than to shocks to sterling.

Movements in sterling have been correlated with movements in the dollar in recent years. A particularly adverse set of circumstances would arise if there were a serious shock to the US economy that also triggered a fall in sterling's value, along with that of the dollar. Under these circumstances, the likely impact on the Irish economy would be greater than that shown for a US equity price shock on its own. However, the additional adverse effects coming through a weakening of sterling would be significantly smaller than those generated directly by the shock to the US economy. This highlights the growth in Ireland's exposure to shocks to the US economy, affecting the Irish economy both directly and indirectly. 
This analysis would suggest that, when the likely realignment of sterling occurs, if it is not accompanied by any other shocks, the effects on the Irish economy will be unfavourable, but the magnitude of any adverse effects will be small.

\section{Inflation in a Regional Economy in EMU - Ireland}

The pick-up in the rate of inflation in consumer prices in Ireland in the last few months has given rise to concerns about the future. In the context of monetary union, some of these concerns are misplaced. However, when the broader developments in prices, in particular in asset prices, are taken into account there are genuine worries that should prompt a change in fiscal policy, the key instrument within monetary union for controlling regional inflationary pressures.

In Ireland, since the mid-1970s, policy-makers have understood that the rate of inflation of consumer goods is ultimately determined by external inflationary pressures and changes in the exchange rate. Under these circumstances, within monetary union, regional goods price inflation will tend to follow that of the union as a whole and the monetary authorities will not pay too much attention to regional variations. You will not hear of the US Federal Reserve worrying about the rate of inflation in Wyoming.

However, Ireland faces a more complex situation than many other members of the EMU because of the very heavy weighting of UK firms in its retail sector, and because of the importance of UK firms as suppliers of imports. As discussed earlier, the "inflationary surprise" of the last two years was not the rise in consumer prices in the last three months, but rather that the rate of consumer price inflation did not rise dramatically in early 1998 when sterling's value in Irish pound terms rose rapidly. The failure of inflation in the price of consumer goods to respond at the time reflected a change in behaviour of UK firms faced with the impending monetary union.

What we are seeing today in the acceleration in the rate of inflation in consumer prices is a combination of a number of factors: a very big increase in oil prices, the increase in tax on tobacco imposed in the December budget, and rapidly rising prices for private services. It is the latter factor - inflation in the price of private services, that is of concern. International competition has little direct impact on the price of sheltered services and domestic wage inflation is passed fully through to consumers. There is no doubt that Irish wage inflation is higher than in our EU neighbours, but that is not necessarily a cause for immediate concern. The tightening labour market is driving this increase, and, as discussed above, some loss of competitiveness is inevitable.

The concern about this trend is whether it will continue for a number of years, leading to such a loss of competitiveness that unemployment eventually rises. The rise in the price of domestic services will, in turn, feed back on wage rates and the competitiveness of the tradable sector. Under monetary union such an overshoot in wage rates could only be tackled through increased labour market flexibility through two possible channels: an actual reduction in nominal wage rates or a wage freeze for a number of years. The former would be both a painful and difficult process. In the case of the latter, while nominal wages could remain static for a period, with inflation effecting a reduction in 
real rates, this could take some time in a low inflation environment. Slow adjustment under such circumstances would have a high cost in terms of unnecessary unemployment.

The developments in inflation, including wage inflation, must be seen as part of a wider convergence process. Irish goods prices were brought broadly into line with goods prices elsewhere in the EU over the last 20 years. The completion of the internal market played an important role in this process. Wage rates, and consequently services' prices, faced less pressure to converge. However, as Irish living standards move towards the EU average, there will be a tendency for this to be reflected in the labour market and in services' prices. Even in the long term this process of price convergence will be much weaker than in the case of goods' prices, and policies to increase competition could significantly improve the end result.

Thus, countries that are experiencing convergence in living standards are likely to face higher inflation than countries that are already at the EU average. ${ }^{6}$ However, this difference in inflation rates should not necessarily cause concern as, when convergence is attained, the process driving the accelerated inflation will disappear. It is only if the price convergence is occurring so rapidly that an overshoot takes place that policy may need to be changed.

Where there is real cause for concern today about the sustainability of the current growth is in the inflation in asset prices - housing and other property. Its immediate impact is to add to labour cost pressures. However, it also has wider implications with the potential to cause real regional problems in any monetary union. This has happened in the past in the US. Here we should be concerned because of the danger that the rise in property prices could greatly overshoot its long-run equilibrium level and that there could be a sudden "bust" brought on by an external shock.

For the bulk of the population who are well housed, the rise in the cost of accommodation will not affect their standard of living. However, the households most adversely affected by rising inflation are those seeking accommodation today. They face rapidly escalating house prices and no feasible increase in incomes or tax cuts could compensate them for their loss. Instead the solution must lie in the broadly canvassed supply side measures.

The costs of accommodation would appear to be higher in our cities than in those of most of our European partners. In the long run the cost of building should be no greater in Ireland than elsewhere - we have more abundant supplies of land than around Amsterdam or Brussels. The problem is the absence of serviced sites and the labour shortage that has arisen due to the exceptional growth rates faced by the industry. If the problems of land availability are tackled urgently, over time, the industry and the labour market will adjust, and the cost of new building should eventually be significantly lower

\footnotetext{
${ }^{6}$ The Balassa-Samuleson effect - higher productivity in the economies converging from below will be reflected in higher wage inflation. In turn, this will result in higher inflation in consumer prices in the converging economy.
} 
than today. In the short term, the use of fiscal measures to take money out of the housing market would ease inflationary pressures.

The likelihood that current prices for dwellings are probably well above their long-run supply price, and that the inflation in prices is being driven by consumers' expectations about the future, means that any sudden shock to the economy and buyers' expectations could cause a serious, though temporary, recession. The fact that such an event seems far away now is not a reason for ignoring it. The "safe stopping" or braking distance of the economy can be quite long so that if the dangers posed by local asset price inflation are to be controlled, fiscal policy, the only instrument available to the government, should already have been tightened in the last few budgets. The economy may still get away with the stimulatory fiscal measures being adopted in successive budgets, but the possible dangers are certainly enhanced by the current stance of policy.

The wage increases provided under the draft Programme for Prosperity and Fairness (PPF) agreement seem reasonable and within the range that the economy can be expected to carry. In the absence of an agreement, market forces might well deliver similar increases, though the process of local bargaining could be more painful and wasteful of resources.

What could destabilise this process is the continuing very rapid increase in the demand for labour, encouraging an overshooting in wage rates beyond their long-term sustainable level. With demand picking up in the wider EU economy the stimulatory nature of domestic fiscal policy is increasing this danger. While tax cuts can affect labour supply, their immediate impact on demand is much greater, leading to enhanced inflationary pressures in the labour market.

\section{The Role of Fiscal Policy}

As argued above, the dangers that may arise from regional inflation within a monetary union are more limited than in the case of economies outside a monetary union. In the end the discipline of the union will regulate the rate of goods price inflation and will also exert some discipline on the price of services. However, there remains the danger that excess demand for labour may set off a process of wage inflation that may be difficult to unwind or even to halt. There is a particular danger that may arise from inflation in regional asset prices, principally the price of property.

Because property is non-tradable and because the supply response to changing prices is slow, it is possible for bubbles to grow and burst in regional property markets within a monetary union. We have seen cases of this happening in the mid-west of the USA in the mid-1980s and somewhat later in Massachusetts. In both these cases the bursting of the bubble caused significant disruption to the local economies. Where the bursting bubble is also accompanied by a collapse of regional financial institutions the impact of the shock can be greatly aggravated. This was the case in the 1980s collapse in the mid-west of the US and it was also the case in the collapse in property prices in Scandinavia around 1990. 
While the loss of the instrument of monetary policy limits the scope for member governments of a monetary union to control their economies, they still have a range of other instruments available to them. As discussed in the introduction, in promoting economic development they have a wide range of supply side policies to choose from. The policies available to control regional inflation and to limit the consequences of any bubble in regional asset prices are prudential action by the Central Bank and fiscal policy.

For the financial system, the implementation of normal prudential safeguards by the Central Bank can ensure that the system is robust in the face of all likely shocks. In the case of Ireland, the major financial institutions are quite diversified in terms of their geographical interests (outside Ireland) and also in terms of their asset portfolio within Ireland. Irish property does not form a major part of their assets. For smaller institutions, more dependent on the Irish market the use of financial instruments, in particular mortgage securitisation, can reduce their domestic market exposure to the property sector.

In the case of the mid-west of the US in the 1980s, the effects of restrictive banking laws made the local financial system very vulnerable to local shocks. In the wake of the problems of the 1980s, there has been some liberalisation of US banking laws and the Federal Reserve Board of Kansas has actively promoted the use of securitisation to further reduce the local financial system's vulnerability. However, in the EU the financial system is generally much more diversified and less vulnerable to regional shocks.

Finally, all the evidence points to a much lower exposure of the household sector in Ireland to financial shocks. In spite of the rapid expansion in finance for investment in housing in recent years, the level of indebtedness of the household sector remains low by international standards and the average size of mortgage, relative to the valuation of the related property, is also low.

While prudential behaviour by financial institutions and individual households can minimise the consequences of any shock to the system, it is not a suitable substitute for monetary policy in controlling domestic inflationary pressures. In a fully integrated financial market, any attempt to regulate the lending behaviour of domestic financial institutions would not be permitted under EMU and it would in any event be totally ineffective. Credit controls on domestic institutions would immediately be outflanked by competition from foreign institutions.

The key instrument still available to governments within EMU to control regional inflationary pressures is fiscal policy. Depending on the factors driving regional inflation, fiscal policy can be a quite effective instrument of policy. In Ireland today the pressures are particularly acute on the labour market where excess demand for labour is driving up wage rates. This, in turn, is giving rise to quite rapid inflation in the price of privately provided domestic services (Meyler, 1999). Where, the inflationary pressures are coming from outside the economy domestic fiscal policy will obviously be less effective. 
Figure 8: Measure of Budgetary Stance

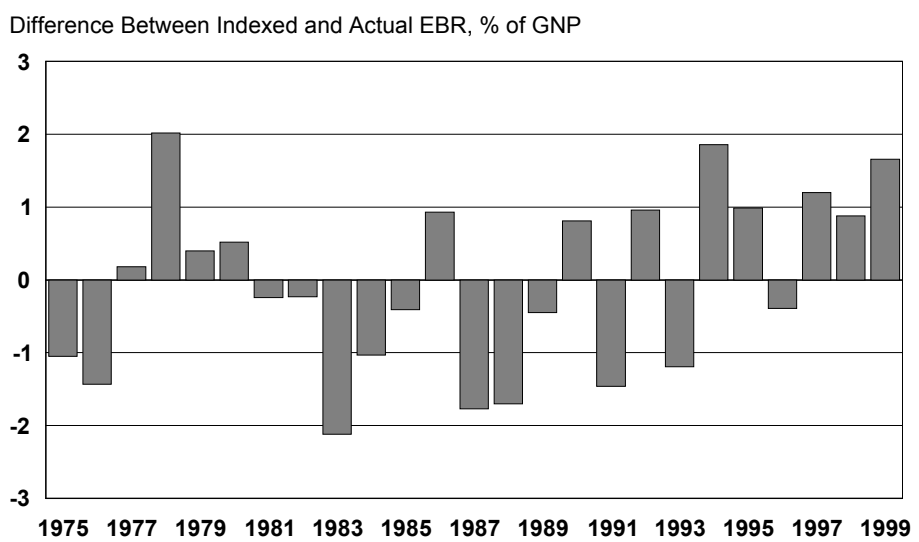

Figure 9: Effect of Fiscal Policy Indexation from 1974-99

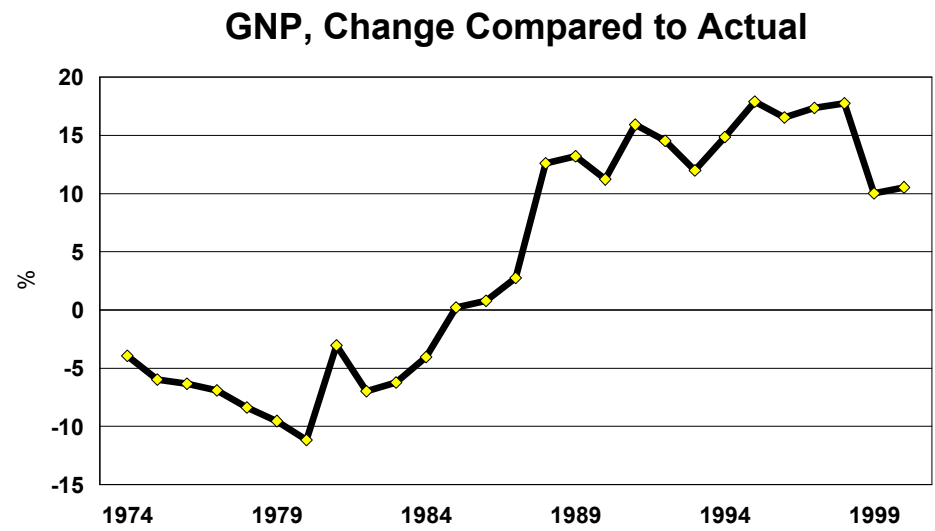

A wide range of studies over the last 20 years have all indicated that domestic fiscal policy can have a significant impact on domestic demand for labour. (Fitz Gerald and Keegan, 1982, Bradley et al., 1993, Barry and Bradley, 1991, Bradley and Whelan, 1995). As shown in Figure 8 (Duffy, Fitz Gerald, Kearney and Smyth, 1999), over the course of the 1980s fiscal policy was strongly deflationary. The cumulative impact of the tight fiscal policy over the decade was to take 8 percentage points of GNP out of the economy. The result of this necessary deflation was a major fall in employment.

The impact of the tightening of fiscal policy in the 1980s is shown in Figure 9. This shows the path GNP would have taken if a neutral fiscal policy had been pursued over the 25 years from 1974 to 1999 . Such a fiscal stance would have been tighter than the actual policy of the 1970s, especially of the 1978-80 period. However, it would have been much laxer than that of the 1980s. By 1990 the effect of the tight fiscal policy of the 1980s was to reduce the level of GNP by 10 percentage points. Obviously any other course of action in fiscal policy would have been unsustainable, this downward adjustment was essential given the fiscal crisis. But this simulation illustrates the point that fiscal policy is an effective instrument for modulating the level of domestic demand in a regional economy. 
Today a tightening of fiscal policy would clearly have an impact on the labour market. Given the limitations on labour supply, a tighter fiscal policy would serve to reduce labour demand resulting, in turn, in a moderation in pressures for higher wage rates. ${ }^{7}$ Membership of EMU has not changed the situation.

One possible argument suggesting that fiscal policy may be less effective today than in the past is that, given the strength of the public finances, any tightening of fiscal policy will inevitably involve a future relaxation. As a result, households may discount such a tightening and borrow against the inevitability of future tax cuts (or expenditure increases). ${ }^{8}$ However, while such forward looking behaviour could somewhat reduce the effectiveness of fiscal policy, this reduction in efficacy is likely to be limited. Many households may be credit constrained, many are risk averse, and the assumption of forward looking behaviour and perfect foresight is clearly extreme.

The area of economic activity where the loss of the monetary policy instrument is particularly felt is in regulating the domestic property market. Because it impacts in particular on the costs of capital, all forms of investment are sensitive to it. Fiscal policy when used for stabilisation purposes, is a much blunter instrument. The Murphy model, Bacon, McCabe, and Murphy,1998, of the housing market indicates that the demand for housing is quite elastic with respect to real income. These results fit in with the results in the HERMES model of the Irish economy. However, even with quite a high income elasticity (close to 2) a very big change is needed in real incomes to make a major impact on housing demand. In making such a large change, the fall-out in terms of the rest of the economy would be quite high.

By contrast, it is possible for monetary authorities to make sufficiently large changes in interest rates to manage effectively the short-term demand for housing. ${ }^{9}$ Because it is better targeted at investment spending it is likely to produce lower "collateral damage".

While fiscal policy applied in a general way may be a relatively blunt instrument for managing demand for property, it is possible to target it more effectively. In particular, the abolition of mortgage interest relief and of all tax support (and other subsidies) for the building industry would produce a more direct impact on housing prices. Irvine, 1984, showed that the abolition of property taxes (household rates) added significantly to house prices in the late 1970s. Similarly the abolition of Residential Property Tax in the 1997 budget contributed significantly to the current housing price boom. A reintroduction of property taxes today would have a very direct impact on house prices.

Even under EMU there are a range of policy options available to governments to manage regional inflationary pressures. Even where these pressures are localised in the property market, the authorities still have significant powers to influence events through the use of

\footnotetext{
${ }^{7}$ It will also reduce labour supply but this effect will be quite small relative to the demand effect.

${ }^{8}$ This argument (Riccardian equivalence) has been considered by Whelan, 1991.

${ }^{9}$ Because there is in theory no limit to high interest rates can be raised they can be used to "scare" potential buyers of property.
} 
targeted fiscal policy measures. The problem that Ireland faces today is that successive governments have shown themselves averse to using these instruments. In this they are clearly reflecting public opinion. However, this is a political problem, not a necessary consequence of membership of monetary union.

While it was widely recognised that the regime shift that monetary union involved had serious consequences for all branches of the private sector there has been a failure by the government sector itself to recognise the changed environment. While advocating policies to promote flexibility in private sector behaviour, successive governments have not fully recognised the implications of the regime shift for the use of the traditional levers of fiscal policy.

\section{Conclusions}

Membership of EMU was expected to bring long-term benefits for the Irish economy through reducing the cost of capital. To date the evidence suggests that this will in fact happen. However, EMU also involves the loss of the monetary policy instrument for use for regulating the economies of individual member states. In the short-term interest rates are too low given the significant local inflationary pressures within the Irish economy. In this paper we have considered some of the things that might go wrong with the Irish economy. This highlights the extent to which the Irish economy's exposure to US economic success (and possible failure) has increased in recent years and the extent to which its exposure to the vagaries of sterling has fallen.

However, while monetary policy is no longer available, other policy instruments are available to manage the regional economy:

Fiscal policy remains a key instrument for all regional governments. Much of the focus of attention over the last few years has centred on the Maastricht guidelines and how they might restrict fiscal policy independence. This has distracted attention from the enhanced importance of fiscal policy for managing the cycle in individual regional economies. While successive Irish governments have highlighted the importance of the regime change for the private sector they have failed to take on board the full implications of the new regime for the role of fiscal policy.

Fiscal policy is a suitable instrument for modulating regional demand for labour. It has been shown to be effective in this role in the past. While less effective in targeting inflationary tendencies in the property market, it can still play an effective role. The major obstacle to using fiscal policy successfully in such a role to replace monetary policy is the difficulty obtaining political acceptance of the necessary unpalatable shortterm measures.

Experience elsewhere has shown that an important precondition for economic success is the maintenance of a sound domestic financial system. The importance of the prudential role of the monetary authorities in regulating the regional financial system needs to be highlighted. However, even a cursory examination of the Irish financial system suggests that it is indeed structured in such a manner that it could ride out any likely regional 
shock. The failings of regional financial systems that contributed to regional crises in the past in the US and Scandinavia do not apply to the Irish system of today.

Much of the argument we see today about the problems in managing the Irish economy relates to a world that never was, never could have been, and never will be. The experience of monetary independence from 1979 to 1998 showed just how limited that independence really was (Honohan and Conroy, 1994). While an independent monetary policy would in theory allow the Irish authorities today to control inflationary pressures in property markets, the reality is that the decision would have been taken out of their hands long ago and market forces would almost certainly have terminated the current boom prematurely. For a small economy such as Ireland the counterfactual to the present regime is not monetary independence but rather a highly constrained environment where uncertainty and information costs would impose a substantial permanent cost to the economy. For an economy the size of the UK monetary independence is more of a reality, though even for the UK its is also highly constrained.

While membership of the EMU reduces the range of instruments available to the Irish authorities to manage the domestic economy, increasing the risk that things might go wrong, EMU membership also reduces the potential economic cost of such an eventuality. Because interest rates and exchange rates are set independently of circumstances in the Irish economy, any purely domestic shock to the Irish economy will have no impact on them. If Ireland were outside the EMU then market forces, even without domestic policy action, would probably have halted the current boom prematurely. If it had not, in the event of a shock to the system, then the consequences would probably have been a very substantial increase in domestic interest rates and a sudden fall in the exchange rate that could be expected to have further aggravated the consequences of such a shock.

It is an illusion to believe that small economies can pursue totally independent monetary policies in a global world. Certainly that was the experience of Ireland over its 20 years of nominal independence. Within EMU the parameters of domestic policy action are reduced, but not eliminated. However, this changed environment requires changes in the way governments manage their economies with more attention being placed on the regional impact of fiscal policy. Member governments have frequently stressed the need for the private sector to adjust to the regime change that EMU membership involves. There is also a need for the governments themselves to recognise this change in formulating their own policies.

\section{References}

Baker, T.J, J. Fitz Gerald, P. Honohan (eds) 1996 The Economic Implications for Ireland of EMU, ESRI Policy Research Series, Paper No. 28, July

Barry, F., and J. Bradley, 1991. "On the Causes of Ireland's Unemployment", The Economic and Social Review, Vol. 22, No. 4, pp. 253-286. 
Bradley, J. ed., 1998, Regional and Policy Impacts of EMU: The Case of Northern Ireland, Belfast, Northern Ireland Economic Council, Research Monograph No. 6.

Bradley, J., J. Fitz Gerald, D. Hurley, L. O'Sullivan and A. Storey, 1993. "HERMES: A Macrosectoral Model for the Irish Economy", in Commission of the European Communities (ed.), HERMES: Harmonised Econometric Research for Modelling Systems, Amsterdam: North Holland.

Bradley, J. and K. Whelan, 1997, "The Irish Expansionary Fiscal Contraction, A Tale from One Small European Economy", Economic Modelling, Vol. 14, No. 12, pp. 175202.

Calmfors, L. ed., 1997, EMU: A Swedish Perspective, Boston: Kluwer Academic Publishers.

Duffy, D., J. Fitz Gerald, I. Kearney and D. Smyth, 1999, Medium-Term Review: 19992005, Dublin: The Economic and Social Research Institute.

Fitz Gerald, J. and O. Keegan, 1982, "The Behavioural Characteristics of the MODEL-80 Model of the Irish Economy", Journal of the Statistical and Social Inquiry Society of Ireland, Vol. XXIV, Part IV.

Fitz Gerald, J., F. Shortall (1998) "Pricing to Market, Exchange Rate Changes and the Transmission of Inflation”, Economic and Social Review, October

Greenslade, J.V., S.G.B. Henry, and R. Jackman, 1998, “A Dynamic Wage-Price Model for the UK", Centre for Economic Forecasting, London Business School, Discussion paper No. 10-98, October

Hall, S., M. Walsh and A. Yates, 1997, "How do UK Companies set prices?" Bank of England Working Paper

Honohan, P., 1993. An Examination of Irish Currency Policy, Dublin: The Economic and Social Research Institute, PRS Paper No. 18.

Honohan, P., and C. Conroy, 1994b. Irish Interest Rate Fluctuations in the European Monetary System, Dublin: The Economic and Social Research Institute, GRS Paper No. 165.

Irvine, I., 1984, A Study of New House Prices in Ireland in the Seventies, Dublin: The Economic and Social Research Institute, General research Series Paper No. 118.

McArdle, P., 2000, "Living With the Euro: A preliminary View", Irish Banking Review, Spring.

Meyler, A., 1999, "Recent Developments in Services Inflation", Central Bank of Ireland Quarterly Report, Dublin, Summer 1999. 
Murphy, A., 1998, "Econometric Modelling of the Irish Housing Market", in An Economic Assessment of Recent House Price Developments, Dublin: The Stationery Office.

Restrictive Practices Commission, 1988. Report of the Restrictive Practices Commission, Dublin: Stationery Office.

Whelan, Karl, 1991. "The Irish Consumption Function and Ricardian Equivalence: The Evidence Re-examined", The Economic and Social Review, Vol. 22, No. 3, pp. 229-238. 